\title{
Gastrin-releasing Peptide in Human Nasal Mucosa
}

James N. Baraniuk, Jens D. Lundgren, ${ }^{*}$ Julie Goff, ${ }^{\ddagger}$ David Peden, Marco Merida, ${ }^{5}$ James Shelhamer, ${ }^{*}$ and Michael Kaliner Allergic Diseases Section, Laboratory of Clinical Investigation, National Institute of Allergy and Infectious Diseases, Bethesda, Maryland 20892; *Critical Care Medicine Department, Clinical Center, National Institutes of Health, Bethesda, Maryland 20892;

${ }^{\ddagger}$ Division of Virology, Georgetown University, Washington, DC 20852; and ${ }^{\S}$ Departments of Otolaryngology and Pediatrics, Georgetown University Hospital, Washington, DC 20007

\begin{abstract}
Gastrin-releasing peptide (GRP), the 27 amino acid mammalian form of bombesin, was studied in human inferior turbinate nasal mucosa. The GRP content of the mucosa measured by radioimmunoassay was $0.60 \pm 0.25 \mathrm{pmol} / \mathrm{g}$ tissue $(n=9 \mathrm{pa}$ tients; mean \pm SEM). GRP-immunoreactive nerves detected by the immunogold method of indirect immunohistochemistry were found predominantly in small muscular arteries, arterioles, venous sinusoids, and between submucosal gland acini. ${ }^{125}$ I-GRP binding sites determined by autoradiography were exclusively and specifically localized to nasal epithelium and submucosal glands. There was no binding to vessels. The effects of GRP on submucosal gland product release were studied in short-term explant culture. GRP (10 $\mu \mathrm{M})$ significantly stimulated the release of the serous cell-specific product lactoferrin, and $\left[{ }^{3} \mathbf{H}\right]$ glucosamine-labeled glycoconjugates which are products of epithelial goblet cells and submucosal gland cells. These observations indicate that GRP released from nerve fibers probably acts on glandular GRP receptors to induce glycoconjugate release from submucosal glands and epithelium and lactoferrin release from serous cells, but that GRP would probably not affect vascular permeability. (J. Clin. Invest. 1990. 85:998-1005.) gastrin-releasing peptide $\cdot$ human inferior turbinate nasal mucosa $\bullet$ respiratory glycoconjugates • lactoferrin • explant culture
\end{abstract}

\section{Introduction}

Gastrin-releasing peptide (GRP) ${ }^{1}$ is a 27 amino acid $(2,859$ $\mathrm{g} / \mathrm{mol})$ mammalian peptide $(1,2)$ that shares sequence homology with bombesin (3), a 14 amino acid amphibian peptide. The common carboxy-terminal sequence is essential for receptor recognition and biological activity. Other GRP-related peptides include GRP [18-27] (GRP [10]; neuromedin C), and GRP[14-27] (GRP[14]; references 3 and 4). GRP is located in nerve fibers (1) and pulmonary neuroendocrine cells (1), and can be detected in plasma $(5,6)$. GRP acts as a neurotransmitter $(7,8)$, a neuroregulatory hormone $(1,9)$, and a growth

Address reprint requests to Dr. Michael Kaliner, Allergic Diseases Section, Laboratory of Clinical Investigation, Building 10, Room 11-C-205, National Institute of Allergy and Infectious Diseases, Bethesda, MD 20892.

Received for publication 26 April 1989 and in revised form 27 October 1989

1. Abbreviations used in this paper: GRP, gastrin-releasing peptide; $\mathrm{P} 1$, period 1; P2, period 2.

The Journal of Clinical Investigation, Inc.

Volume 85, April 1990, 998-1005 factor in fetal (10), normal (11), and neoplastic $(12,13)$ respiratory tissues (1). Recently, it has been demonstrated that GRP significantly stimulates mucus secretion from cat trachea maintained in explant cultures (14). GRP is also a stimulant of pancreatic exocrine secretion $(15,16)$ and a participant in the central and vagal control of gastric mucosal homeostasis (17-19). Therefore, GRP is an exceedingly interesting peptide which may have many relevant effects on respiratory tissues.

To investigate the potential roles of GRP in human respiratory mucosal function, human inferior nasal mucosa was analyzed for GRP content by RIA, for the presence of GRP-immunoreactive nerves and other GRP-containing structures by indirect immunohistochemistry, and for the presence of GRP binding sites by autoradiography. The secretogogue activity of GRP was assessed by culturing human nasal mucosal fragments with GRP and measuring the secretion of lactoferrin, a product of submucosal gland serous cells (20), and acid-precipitable, $\left[{ }^{3} \mathrm{H}\right]$ glucosamine-labeled respiratory glycoconjugates $(21,22)$

\section{Methods}

Tissue handling. Human inferior turbinate tissue was obtained from 14 patients with nasal obstruction syndromes. At the time of surgery, $2 \%$ tetracaine $\mathrm{HCl}$ and $0.25 \%$ phenylephrine $\mathrm{HCl}$ were applied topically on nasal packs. The turbinates were injected with $2-4 \mathrm{ml}$ of $1 \%$ lidocaine with 1:100,000 epinephrine. The infero-lateral portions of the inferior turbinates were excised. Tissue was prepared for immunohistochemistry (see below), frozen in 2-methyl-butane for $30 \mathrm{~s}$, and stored at $-70^{\circ} \mathrm{C}$ until required, or placed in L15 transport media (Biofluids, Rockville, MD) supplemented with penicillin, streptomycin, and amphotericin before explant culture.

Extract preparation. Frozen turbinate tissue from single individuals was weighed (wet weight), finely dissected with razor blades, and suspended $(20 \mu \mathrm{l} / \mathrm{mg}$ tissue) in $50 \%$ ethanol, $50 \% 0.1 \mathrm{~N}$ acetic acid, $0.02 \%$ sodium bisulfite in $4^{\circ} \mathrm{C}$ distilled water. Over a 30 -min period the tissue suspension was sonicated (Heat Systems - Ultrasonics, Inc., Plainview, NY) on ice three times for $30 \mathrm{~s}$ each at a setting of 6 . The suspension was centrifuged $\left(1,700 \mathrm{~g}, 30 \mathrm{~min}, 4^{\circ} \mathrm{C}\right)$ and the supernatant aspirated, frozen, and lyophilized.

RIA. Lyophilized, powdered extracts were resuspended in RIA buffer $(0.1 \%$ BSA, pH 7.4, $0.1 \mathrm{M}$ sodium phosphate, $0.05 \mathrm{M} \mathrm{NaCl}$, $0.01 \% \mathrm{NaN}_{3}, 0.01 \%$ Tween-80) so that a quantity of extract equivalent to $40 \mathrm{mg}$ of original tissue mass was suspended in $100 \mu \mathrm{l}$ of RIA buffer. Standard GRP solutions were prepared for the range from 2.5 to 256 $\mathrm{pg} /$ tube (0.87-90 fmol/tube). Samples of ethanol-acetic acid extracts of human nasal mucosa were also added to known amounts of GRP to determine if the addition of tissue extracts altered the conditions of the RIA. The turbinate extract preparations were reconstituted in RIA buffer, diluted, and aliquotted to give 40,13 , and $4 \mathrm{mg}$ of turbinate tissue/tube. Rabbit anti-GRP (1:1,000; Amersham Corp., Arlington Heights, IL) was added. After overnight incubation at $4^{\circ} \mathrm{C}, 20,000 \mathrm{cpm}$ of 3- ${ }^{125} \mathrm{I}-\mathrm{tyr}^{15}$-GRP $(2,013 \mathrm{Ci} / \mathrm{mmol}$; Amersham Corp. $)$ was added. After $48 \mathrm{~h}$ of incubation at $4^{\circ} \mathrm{C}$, polyclonal goat anti-rabbit gamma 
globulin (1:1,000; Peninsula Laboratories, Inc., Belmont, CA) and nonimmune rabbit serum were added for $2 \mathrm{~h}$ at room temperature. RIA buffer was added and the tubes were centrifuged. Radioactivity in the pellets was counted in a gamma scintillation counter (Beckman Instruments, Inc., Irvine, CA) and the percentage of bound to total counts per minute determined.

The linear portions of standard curves were analyzed by linear regression and the yield of GRP/tube interpolated. The mean $( \pm$ SEM) picomoles GRP/gram turbinate tissue was calculated.

HPLC. Nasal tissue was extracted in ethanol-acetic acid, lyophilized, and reconstituted in $0.12 \%$ trifluoroacetic acid (Sigma Chemical Co., St. Louis, MO). After 30 min nonsoluble material was removed by centrifugation. A $150-\mu$ l aliquot of extract, synthetic GRP, or synthetic GRP[10] was applied to a high pressure liquid chromatogram (114M pumps, 421 controller, and 164 detector; Beckman Instruments, Inc., Fullerton, $\mathrm{CA}$ ) using a $\mathrm{C}-18$ reverse phase column (ODS Ultrasphere, $4.6 \times 25 \mathrm{~cm}, 5 \mu \mathrm{m}$ pore size; Beckman Instruments Inc.). Samples were eluted over a $45-\mathrm{min}$ period using an increasing percentage of $0.12 \%$ trifluoroacetic acid in acetonitrile in the original solvent $(0.12 \%$ trifluoroacetic acid in water). The linear gradient began at $0 \%$ acetonitrile solution in water solution and ended at $90 \%$. Fractions were collected at 1-min intervals, frozen, lyophilized, and reconstituted in RIA buffer. The GRP content of each fraction was determined by RIA.

Indirect immunohistochemistry. Tissues for immunohistological examination were placed in plastic scintillation vials (Kimble Div., Owens-Illinois, Inc., Toledo, $\mathrm{OH}$ ) with $10 \mathrm{ml}$ of $1.5 \%$ paraformaldehyde and $0.05 \%$ glutaraldehyde in $\mathrm{pH} 7.4,0.05 \mathrm{M}$ sodium phosphate, $0.1 \mathrm{M} \mathrm{NaCl}$ (PBS) at room temperature and exposed to microwaves (400 W; Sharp Electronics Corp., Mahwah, NJ) for 5 s (23). The temperature of the solution was raised to $45 \pm 5^{\circ} \mathrm{C}$ by this exposure. The tissue was stored in PBS $\left(4^{\circ} \mathrm{C}\right)$ before being embedded in paraffin (American Histolabs, Gaithersburg, MD). Microwave fixation allowed rapid tissue processing, excellent preservation of tissue histology, and improved identification of GRP-immunoreactive nerve fibers when compared with other fixation techniques (23).

Paraffin sections were defatted in xylene and exposed sequentially to graded alcohols, distilled water, PBS, and PBS with $1 \%$ nonimmune goat serum (24). Sections were incubated for 18 or $44 \mathrm{~h}$ at $4^{\circ} \mathrm{C}$ with rabbit anti-GRP $(1: 1,000)$ or anti-GRP adsorbed with $1 \mu \mathrm{M}$ GRP. The slides were washed with PBS and exposed to $1 \%$ nonimmune goat serum in PBS for $3 \mathrm{~min}$ at room temperature, and then to 1:40 colloidal gold-labeled goat anti-rabbit gamma globulin (Auroprobe; Janssen Life Sciences Products, Piscataway, NJ) for $60 \mathrm{~min}$ at room temperature. After washing thoroughly in PBS and distilled water, silver enhancing solution (IntenSE; Janssen Life Sciences Products) was added and the development of the stain monitored by light microscopy. Slides were counterstained lightly with nuclear fast red (Sigma Chemical Co.).

Autoradiography. ${ }^{125}$ I-GRP binding was performed using methods adapted from Moran et al. (25) and Kris et al. (26). Cryostat sections $(10 \mu \mathrm{m}$ thick) were warmed to room temperature and washed in CMRL media with aprotinin (400 kallikrein inhibitory units/ml; Sigma Chemical Co.) and $0.5 \%$ BSA for $30 \mathrm{~min}$ at $25^{\circ} \mathrm{C}$. Slides were incubated for $75 \mathrm{~min}$ at $4^{\circ} \mathrm{C}$ with $1 \mathrm{nM} 3-^{125} \mathrm{I}-\mathrm{tyr}^{15}$-GRP (Amersham Corp.) in CMRL/aprotinin/BSA. Specific binding was determined by adding $1 \mathrm{nM}^{125} \mathrm{I}-\mathrm{GRP}$ with and without $2 \mu \mathrm{M}$ unlabeled GRP. After incubation, slides were washed four times each for $30 \mathrm{~s}$ with CMRL/ aprotinin/BSA at $4^{\circ} \mathrm{C}$ and dried with blown cold, dry air.

Nuclear track emulsion (NTB-2; Eastman Kodak Co., Rochester, $\mathrm{NY}$ ) was melted in the dark for $4 \mathrm{~h}$ at $45^{\circ} \mathrm{C}$ and then mixed with an equal volume of $1 \%$ glycerol in water. Slides were dipped in emulsion, allowed to dry in the dark (27), and stored at $-20^{\circ} \mathrm{C}$. Slides were removed at intervals and developed in D-19 developer and fixer (Eastman Kodak Co.) (see reference 27).

Nasal mucosal explant culture $(14,21,22)$. Fresh nasal mucosa was cut into $3 \times 3$-mm fragments. Pairs of fragments were placed on gelfoam in petri dishes, and cultured in $2 \mathrm{ml}$ of CMRL 1066 media containing penicillin $(100 \mu \mathrm{g} / \mathrm{ml})$, streptomycin $(100 \mu \mathrm{g} / \mathrm{ml})$, and am- photericin $(0.5 \mu \mathrm{g} / \mathrm{ml})$ (Grand Island Biologicals, Grand Island, NY), and $\left[{ }^{3} \mathrm{H}\right]$ glucosamine $(1 \mu \mathrm{Ci} / \mathrm{ml}$; New England Nuclear, Boston, MA). The glucosamine is incorporated into newly synthesized respiratory glycoconjugates $(14,21,22)$. After $24 \mathrm{~h}$ the media was changed and aprotinin (400 kallikrein inhibitory units/ml, Sigma Chemical Co.) added to the mixture. This dose of aprotinin has been shown to enhance the effects of peptide secretagogues such as substance $P(21)$, but to have no effect of its own on glycoconjugate release. After an additional $24 \mathrm{~h}$ the explant fragments were washed with media and then incubated with media containing $\left[{ }^{3} \mathrm{H}\right]$ glucosamine and aprotinin for 4 h. The culture media from this baseline period (period 1 [P1]) was collected and then replaced for $1 \mathrm{~h}$ (period 2 [P2]) by media (control plates), media plus $10 \mu \mathrm{M}$ GRP (Peninsula Laboratories, Inc.) and aprotinin, or $100 \mu \mathrm{M}$ methacholine (Sigma Chemical Co.). Three plates were used per treatment.

Quantitation of $\left[{ }^{3} \mathrm{H}\right]$ glycoconjugate release $(21,22)$. Quantitation of glycoconjugate release into the culture media from $\mathrm{P} 1$ and $\mathrm{P} 2$ for each treatment was performed by precipitation of ${ }^{3} \mathrm{H}$-labeled glycoconjugates in $10 \%$ TCA and $1 \%$ phosphotungstic acid at $5^{\circ} \mathrm{C}$ overnight. The precipitates were pelletted by centrifugation $(1,200 \mathrm{~g}$ for 10 $\mathrm{min}$ ), washed twice with TCA-phosphotungstic acid, and hydrolyzed in $0.1 \mathrm{~N} \mathrm{NaOH}$. Aliquots of the dissolved precipitates were used for scintillation counting. The ratio of disintegrations/minute in the supernatants collected during P2 to disintegrations/minute for P1 (secretory index) was calculated for each treatment $(21,22)$. The mean $( \pm$ SEM) percent change in secretory indices for the GRP- or methacholine-treated plates compared with control plates were calculated. The secretory indices for each experimental treatment were compared with the control values by unpaired $t$ test. Comparisons of the percent change in glycoconjugate secretion provided a quantitative estimate of the effects of the agents on radiolabeled glycoconjugate release $(21,22)$.

Lactoferrin ELISA. The lactoferrin concentration in culture media from $\mathrm{P} 1$ and $\mathrm{P} 2$ for each treatment was measured using a noncompetitive ELISA (28). Microtiter plates were coated with $100 \mu l$ of rabbit anti-human lactoferrin (Dako Corp., Santa Barbara, CA), diluted $1: 1,000$ in $\mathrm{pH} 9.6,0.1 \mathrm{M}$ carbonate buffer, and incubated at $4^{\circ} \mathrm{C}$ overnight. The wells were washed with 4 vol of a buffer (PT), pH 7.4, consisting of $50 \mathrm{mM}$ sodium phosphate, $0.1 \mathrm{M} \mathrm{NaCl}, 0.05 \%$ Tween- 80 (Fischer Scientific, Fairlawn, NJ). After blocking nonspecific binding sites with $1 \%$ goat serum (Gibco Laboratories, Grand Island, NY) in PT for $30 \mathrm{~min}$ at room temperature, $100 \mu \mathrm{l}$ of media or standard (diluted in PT) was added to each well and incubated at $37^{\circ} \mathrm{C}$ for 90 min. Goat anti-human lactoferrin conjugated to horseradish peroxidase (100 $\mu \mathrm{l}$; Organon Teknika - Cappel Laboratories, West Chester, PA) was added and incubated at $37^{\circ} \mathrm{C}$ for $90 \mathrm{~min}$. The color reaction was developed with $o$-phenylenediamine di- $\mathrm{HCl}$ (Sigma Chemical Co.), and the optical density at $490 \mathrm{~nm}$ read for each well on an ELISA reader. The ratios of optical densities from the supernatants collected during P2 to those for P1 (secretory index) were calculated for each treatment, and the mean $( \pm$ SEM) percent change in secretory indices from control values were calculated. The secretory indices for each treatment were compared with the control values by unpaired $t$ test.

\section{Results}

$R I A$. The sigmoid standard curve was linear between 5 and 80 $\mathrm{pg} /$ tube ( 1.7 and $28 \mathrm{fmol} /$ tube). Using linear regression, the squares of the correlation coefficients for the standard curves were between 0.96 and 0.996 . The sensitivity (concentration at $\left.\mathrm{B} / \mathrm{B}_{0}=50 \%\right)$ of the assay was $3.39 \pm 0.12(n=4) \mathrm{fmol} /$ tube. The addition of ethanol - acetic acid extract of nasal tissue equivalent to $10 \mathrm{mg}$ of nasal mucosa did not affect the shape of the standard curve, but did shift the curve in parallel fashion to the right. $\mathrm{By}$ interpolation of $\mathrm{B} / \mathrm{B}_{0} \%$ values between 20 and $90 \%$, the GRP content of human turbinate nasal mucosa was 
estimated to be $0.60 \pm 0.09 \mathrm{pmol} \mathrm{GRP} / \mathrm{g}$ tissue ( $n=9$ patients). Contents ranged from 0.18 to $0.89 \mathrm{pmol} / \mathrm{g}$.

HPLC. Synthetic GRP $(25 \mu \mathrm{g})$ eluted from the HPLC column with a single, narrow peak optical density peak at 23.7 min. GRP[10] eluted at $32.6 \mathrm{~min}$. Using the RIA, synthetic GRP eluted only in the fraction collected between 24 and 25 min. When turbinate tissue was eluted from the HPLC column, there were many peaks eluted between 0 and $40 \mathrm{~min}$. Using the RIA, GRP immunoreactive material was eluted only in the fraction collected between 24 and $25 \mathrm{~min}$. All other fractions for both the standards and tissue contained no immunoreactive GRP. Therefore, human nasal turbinate GRP immunoreactive material eluted at the same time as synthetic GRP.

Indirect immunohistochemistry. GRP-immunoreactive nerves were widely distributed in human nasal mucosa. Arterioles were densely innervated by a plexus of GRP immunoreac- tive nerves (Fig. 1). Fibers were most concentrated along the adventitial border and between vascular smooth muscle cells, although some did appear to penetrate to the intima. The walls of venous sinusoids and venules were innervated by individual fibers (Fig. 2). Both varicose (neurosecretory) and smooth fibers were found. Individual fibers were also noted in submucosal glands between gland acini in close apposition with both the mucous and serous secretory cells (Fig. 3 ). Free fibers were found occasionally in connective tissues and beneath the epithelial basement membrane. Deep mucosal nerve bundles were found that contained a population of intensely stained GRP-immunoreactive neurons (not shown). No GRP-containing epithelial or neuroendocrine cells were found in human nasal mucosa. No specific staining was found if antiserum adsorbed with excess GRP was used.

Autoradiography. ${ }^{125}$ I-GRP binding sites were identified in human nasal mucosa. ${ }^{125}$ I-GRP bound specifically to the epi-

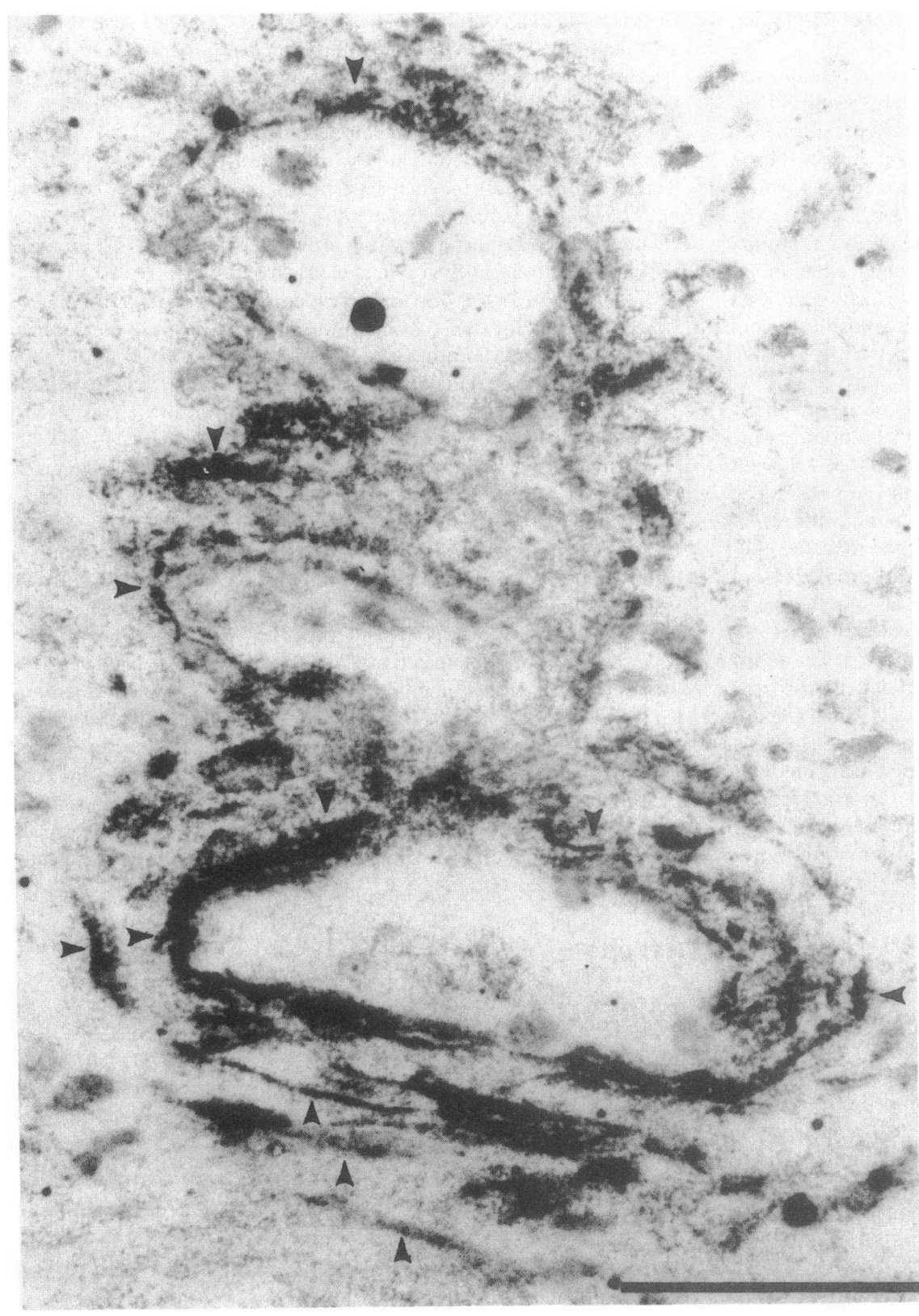

Figure 1. GRP innervation of arterioles. GRPimmunoreactive nerve fibers appear as darkly stained fibers and are indicated by arrowheads in this section of human inferior turbinate nasal mucosa. These GRP neurons densely innervate this coiled arteriole. They are found at the adventitial-medial junction, between smooth muscle cells, and extend inward to the intima. Bar $=25 \mu \mathrm{m}$. 


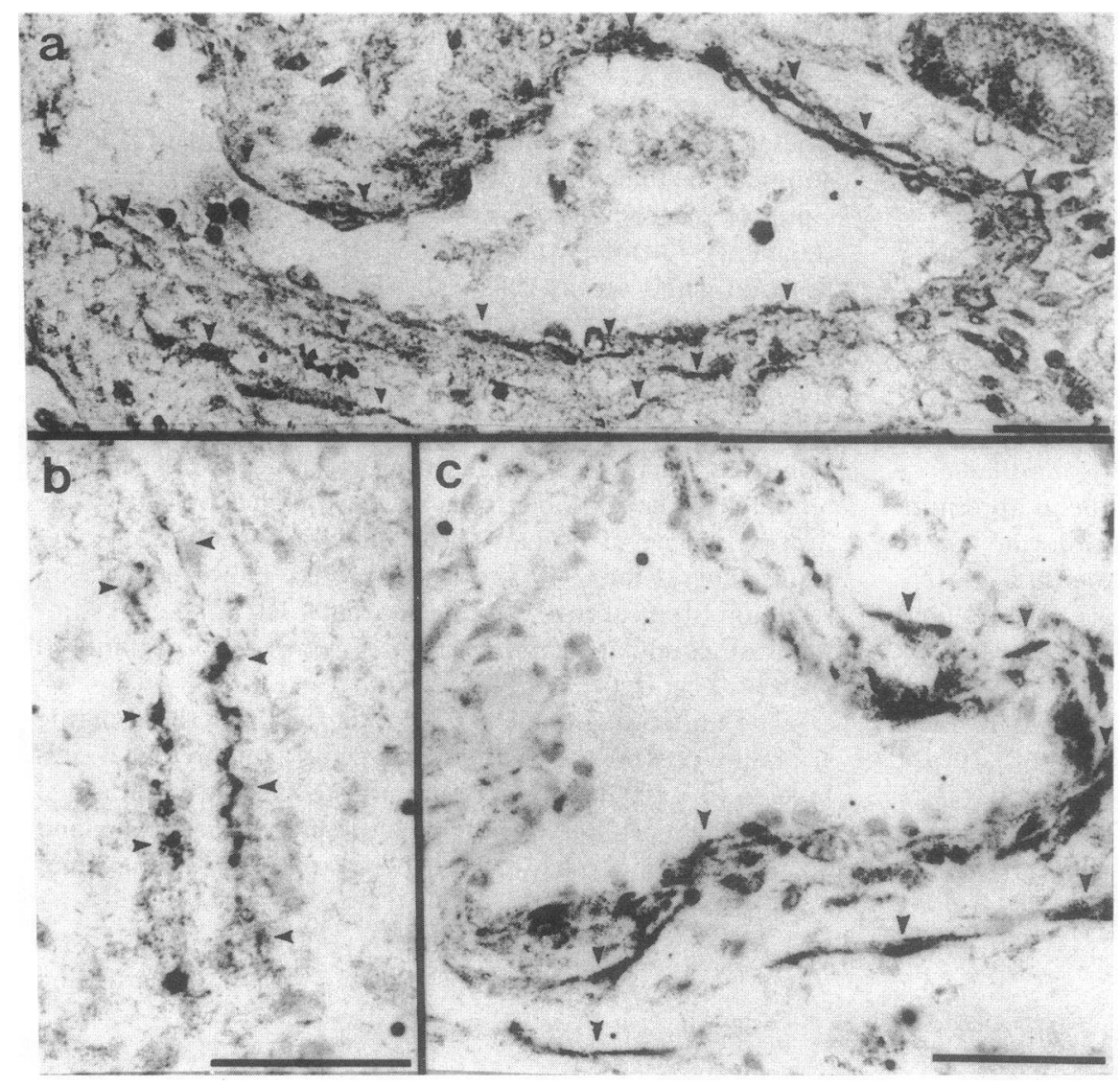

Figure 2. GRP innervation of vessels. GRPimmunoreactive neurons are seen as dark fibers in these vessels. The arrowheads denote selected examples of GRP-containing neurons. Both smooth and varicose (neurosecretory) regions of individual fibers can be seen. $a$, GRP neurons densely innervate the walls of a venous sinusoid. $b$, Parallel GRP nerve fibers are demonstrated in the walls of a superficial arteriole near the epithelial basement membrane. $c$, Several fibers are seen in the walls of this obliquely cut arteriole. Nuclear fast red counterstain was used. Bars $=25 \mu \mathrm{m}$.

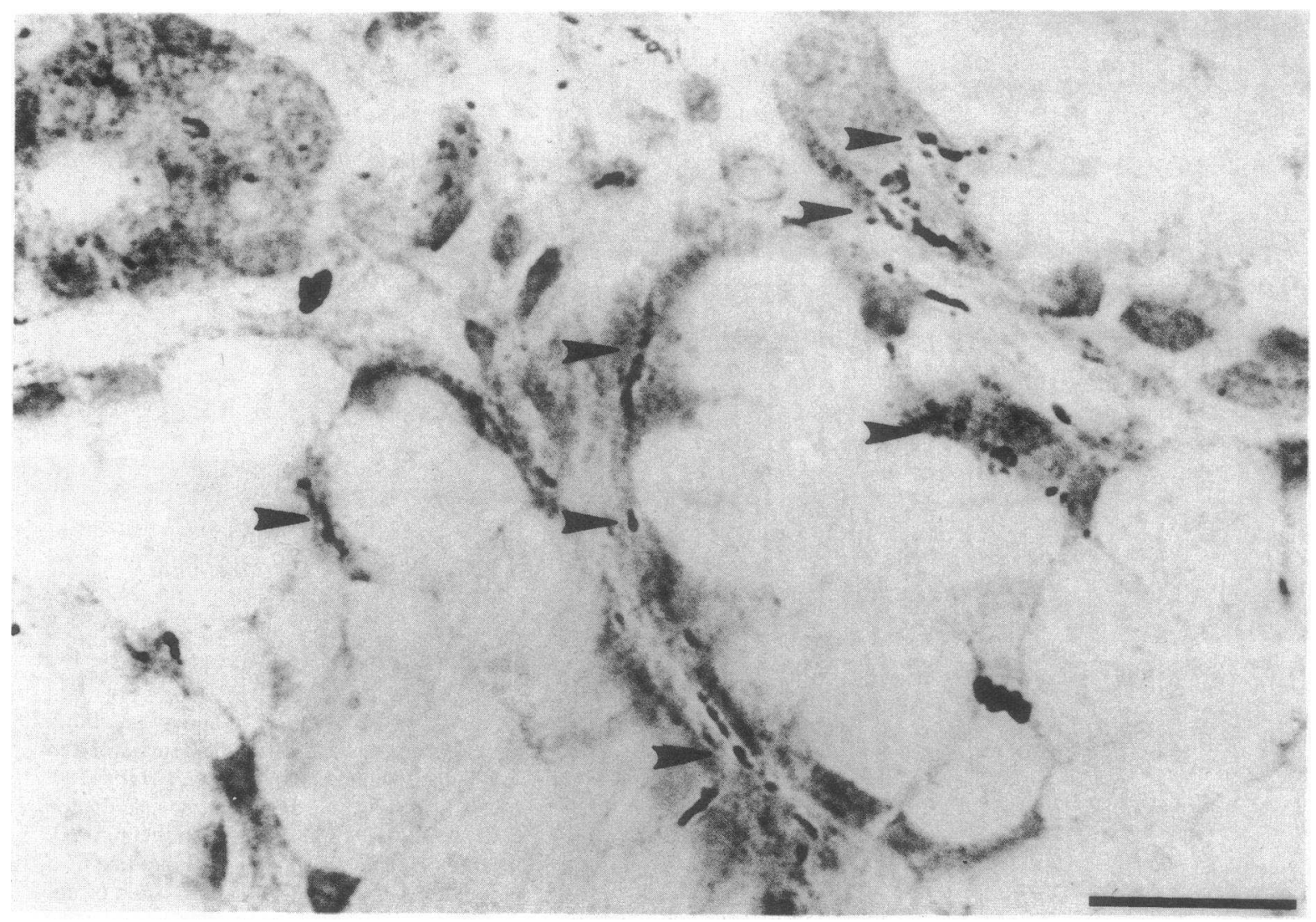

Figure 3. GRP innervation of glands. GRP-immunoreactive neurons are seen as dark fibers (arrowheads) in close apposition to large, clear mucous cells of submucosal glands. Serous cells were similarily innervated by these varicose fibers. Nuclear fast red counterstain was used. Bar $=25 \mu \mathrm{m}$. 
thelium and submucosal glands (Figs. 4, 5, and 6). All epithelial cells appeared to bind ${ }^{125}$ I-GRP (Figs. 4 and 6), and there did not appear to be a preference for goblet cells or other cell types. Both mucous and serous cells of submucosal glands bound ${ }^{125}$ I-GRP (Figs. 5 and 6). Vessels did not exhibit ${ }^{125} \mathrm{I}-$ GRP binding (Figs. 5 and 6). The addition of excess GRP prevented binding of ${ }^{125}$ I-GRP to epithelium (Fig. 4) and submucosal glands (Fig. 5).

Explant culture: GRP (10 $\mu \mathrm{M})$ significantly stimulated $\left[{ }^{3} \mathrm{H}\right]$ glucosamine-labeled glycoconjugate release from cultured human nasal mucosal fragments. The secretory indices for GRP cultured media was $21.7 \pm 5.8 \%(n=5)$ greater than control cultures $(P<0.02)$. This effect was not due to aprotinin, since aprotinin by itself did not induce glycoconjugate release $(-1.8 \pm 7.3 \% ; n=3)$. Methacholine challenges $(100 \mu \mathrm{M})$ were included in each days' experiments as positive controls, and stimulated significant glycoconjugate release $(35.7 \pm 2.7 \% ; n$ $=5 ; P<0.001)$.

Lactoferrin, a product of serous cells (20), was released from explant submucosal gland serous cells by both $10 \mu \mathrm{M}$ GRP $(58.1 \pm 3.5 \%$ increase above control release; $n=3 ; P$ $<0.001)$ and $100 \mu \mathrm{M}$ methacholine $(76.1 \pm 24.6 \%$ increase; $n$ $=3 ; P<0.05)$.

\section{Discussion}

These experiments are the first demonstrations that GRP can stimulate lactoferrin- and $\left[{ }^{3} \mathrm{H}\right]$ glucosamine-labeled, acid-precipitable macromolecule release from human nasal mucosal fragments. Lactoferrin is synthesized and secreted from submucosal gland serous cells (20). ${ }^{3} \mathrm{H}$-Respiratory glycoconjugates (mucous) are complex mixtures of mucous glycoproteins, proteoglycans, and other glycoconjugates that are derived from epithelial goblet cells, and submucosal gland serous and mucous cells $(21,22,29)$. These results suggest that secretion from submucosal gland serous and mucous cells and potentially epithelial goblet cells was stimulated by GRP. The limited supply of human tissue did not allow full dose-response curves for GRP to be determined. However, data on secretion from cat trachea indicates that GRP is a potent stimulant of glandular secretion at doses between $10 \mathrm{nM}$ and 10 $\mu \mathrm{M}(14,21)$.

The autoradiographic results indicate that GRP binding sites were present over submucosal glands and epithelial cells in human nasal mucosa. Immunohistochemistry confirmed the presence of GRP-immunoreactive nerves between gland acini of nasal mucosa $(30,31)$. Therefore, based on three lines
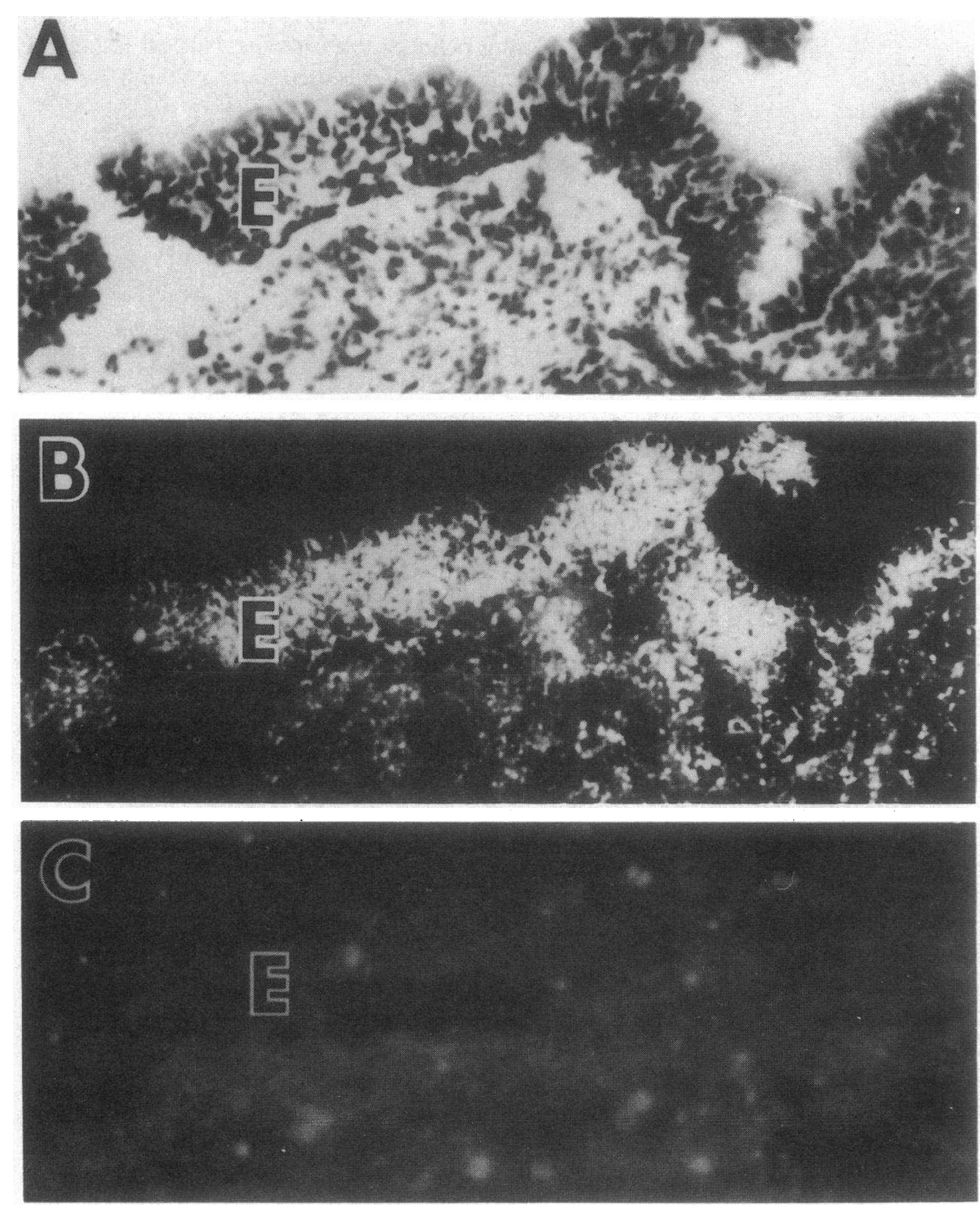

Figure 4. ${ }^{125}$ I-GRP binding to human nasal mucosal epithelial cells. $A$, Brightfield image of a toluidine blue-stained epithelium $(E) . B a r=100$ $\mu \mathrm{m} . B$, Darkfield image of the same field demonstrating ${ }^{125}$ I-GRP binding to the epithelium $(E)$. No specific differences in ${ }^{125}$ I-GRP binding to various cell types in the epithelium could be appreciated. $C$, Darkfield image of an homologous field from an adjacent section treated with $1 \mu \mathrm{M}$ GRP. Excess GRP ablated the ${ }^{125}$ I-GRP binding to the epithelium. 

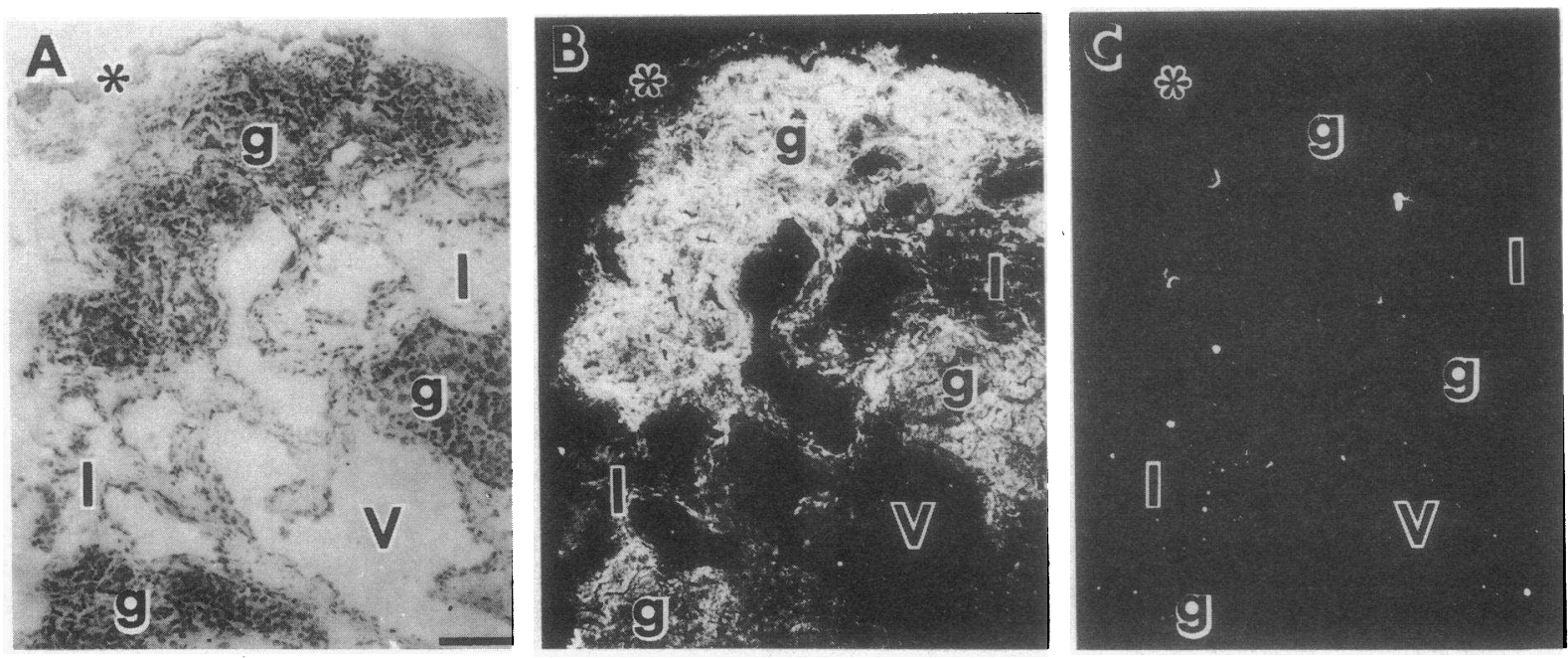

Figure 5. ${ }^{125}$ I-GRP binding to submucosal glands. $A$, Brightfield image of toluidine blue-stained submucosal glands $(g)$, venous sinusoids $(V)$, and interstitial areas $(I)$. An area of partially denuded basement membrane with attached connective tissue and a partial thickness of epithelium is also shown $\left(^{*}\right) . B a r=100 \mu \mathrm{m} . B$, Darkfield image of the same field as $A$, showing that ${ }^{125}$ I-GRP was bound only to submucosal glands $(g)$, and not to the vessels $(V)$ or interstitium $(I)$. The basement membrane and attached tissue $\left({ }^{*}\right)$ did not demonstrate binding. $C$, Darkfield image of a homologous field from an adjacent section treated with $1 \mu \mathrm{M}$ GRP. Excess GRP ablated the ${ }^{125} \mathrm{I}-$ GRP binding.

of evidence it can be concluded that GRP acts as a neurotransmitter that stimulates glandular secretion since: $(a)$ GRP is present in nerve fibers in glands, $(b)$ GRP binding sites are present in glands, and $(c)$ when added exogenously, GRP stimulates gland secretion in vitro.

The curious pattern of innervation and GRP binding sites is of interest. GRP-immunoreactive material was found in arteriolar vessels in nasal mucosa $(2,31)$ but no GRP binding sites were identified on vessels. This observation suggests that the presence of a neuropeptide in a nerve at a given location does not necessarily indicate that the peptide is active at that site. Rather, the presence of receptors and their distribution
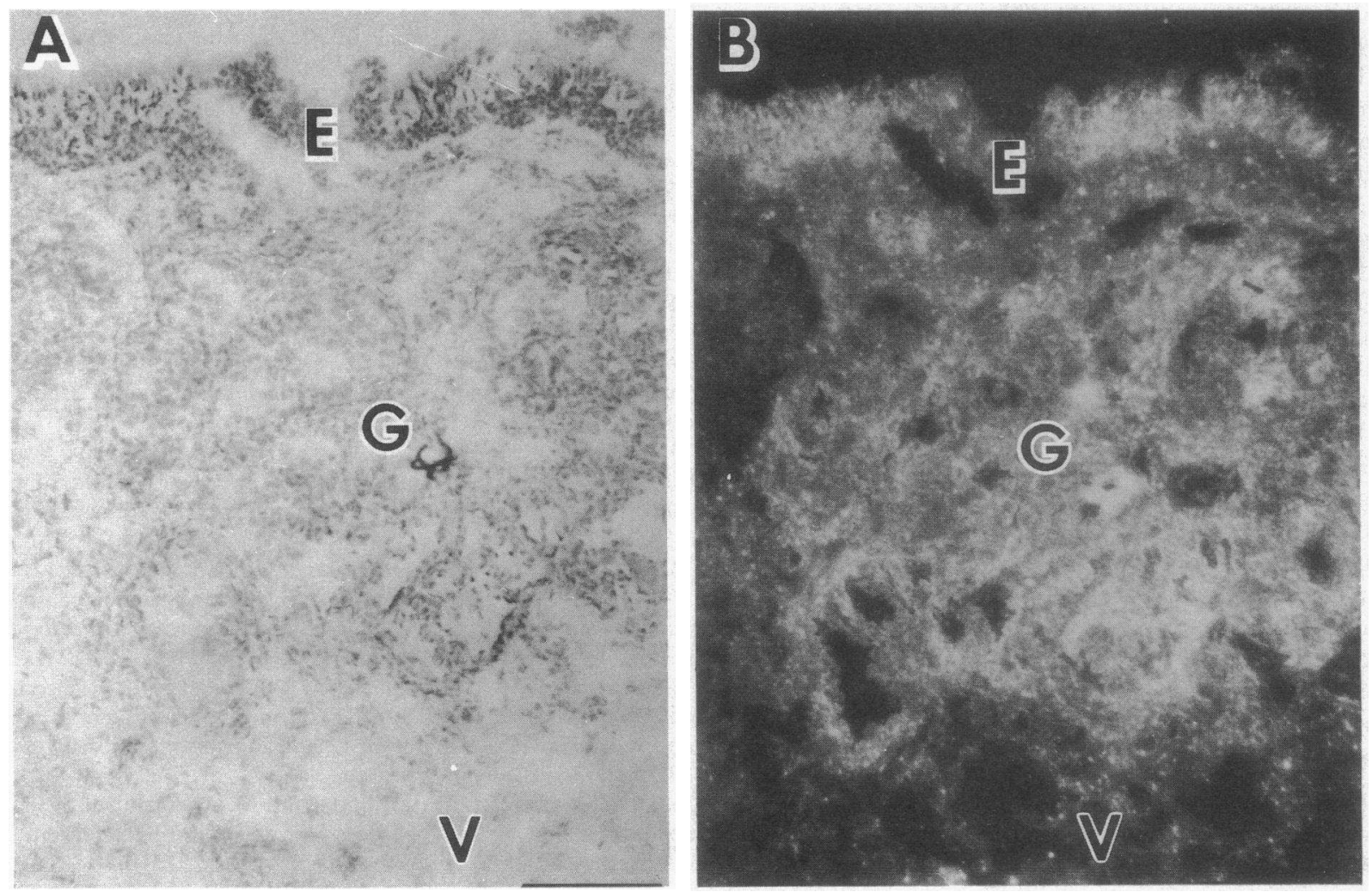

Figure 6. ${ }^{125}$ I-GRP binding to human nasal epithelium. $A$, Brightfield image of toluidine blue-stained epithelium $(E)$, densely packed submucosal glands $(G)$, and venous sinusoids $(V) . B$, Darkfield image of the same field as $A$, showing that ${ }^{125}$ I-GRP was bound only to the epithelium $(E)$ and submucosal glands $(G)$, but not to vessels $(V)$. Bars $=100 \mu \mathrm{m}$. 
probably determines the actions of neurally released peptides. The response pattern may be even more complex and unpredictable, since GRP may be colocalized with other peptides (7). The synergistic (32) or antagonistic (33) effects that result when several peptides are simultaneously released at a single site may be difficult to predict, and may require empiric testing to determine. Such complex interactions have not been studied with GRP.

The origin of GRP-containing neurons is not yet completely defined. In rat spinal sensory ganglia, GRP has been colocalized with substance $P$, suggesting that GRP is present in sensory neurons $(7,31,34)$. Preliminary studies in human nasal mucosa suggest that GRP, calcitonin gene related peptide, and neurokinin A have nearly identical distributions in serial immunohistochemical sections (personal observations, unpublished data). This finding suggests that GRP is localized in trigeminal nociceptive sensorimotor type $C$ nerve fibers. Colocalization studies are in progress to verify this impression.

Should GRP be localized to sensory neurons, then sensory neuron axon reflex activation could lead to the release of GRP near submucosal glands and the epithelium. Axon reflexes have been shown to release substance $P$ and calcitonin gene related peptide from sensory neurons in rat nasal mucosa $(35$, 36), rat tracheobronchial mucosa (37), and guinea pig heart (38), and may contribute to the pathogenesis of asthma (39, 40). GRP release by axon reflex mechanisms, or after capsaicin treatment, has not yet been examined. Given that GRP is a trophic hormone for respiratory tissues $(10-13)$, it may be important to learn the mechanisms that lead to GRP release, and to further understand the effects of GRP on the mucosa.

The HPLC results indicate that GRP and human nasal mucosal GRP-immunoreactive material coelute, and that there is only a single peak of extractable GRP-immunoreactive material. This finding is at variance with an HPLC study of bronchoalveolar lavage fluid which found several "bombesinlike peptides," peptides that bound to anti-bombesin monoclonal antibodies (41). It is possible that the concentration of bombesin-like peptides in the present study may have been too low to detect with the present assay conditions or polyclonal antiserum. However, immunohistochemical staining indicates that in the lower respiratory tract neuroendocrine cells are the prime source of bombesin-like peptides (including GRP; see reference 42). Neuroendocrine cells and specifically GRPcontaining cells were not identified in human nasal mucosa. It is possible that lower respiratory tract neuroendocrine cells contribute the bombesin-like peptides detected in bronchoalveolar lavage fluid, and that these peptides were absent from the upper respiratory tract because of the absence of neuroendocrine cells.

Based upon the original data presented here, GRP appears to be a neurotransmitter capable of inducing secretion from mucous and serous cells of the submucosal glands of human nasal mucosa. Given the dirth of vascular binding sites, GRP may have negligible effects on the tone and permeability of mucosal vessels. Thus, GRP appears be a specific regulator of glandular secretion in human nasal mucosa.

\section{Acknowledgments}

Dr. Baraniuk was supported by a grant from Procter and Gamble Co. Dr. Lundgren was sponsored in part by the Danish Medical Research Council.

\section{References}

1. Sunday, M. E., L. M. Kaplan, E. Motoyama, W. W. Chin, and E. R. Spindel. 1988. Gastrin releasing peptide (mammalian bombesin) gene expression in health and disease. Lab. Invest. 59:5-24.

2. Panula, P. 1986. Histochemistry and function of bombesin-like peptides. Med. Biol. (Helsinki). 64:177-192.

3. Cuittitta, F., J. Fedorko, J. Gu, A. M. Lebacq-Verheyden, R. I. Linnoila, and J. F. Battey. 1988. Gastrin releasing peptide gene associated peptides are expressed in normal human fetal lung and small cell lung cancer: a novel peptide family in man. J. Clin. Endocrinol. Metab. 67:576-583.

4. McKillop, J. M., W. L. Foy, C. F. Johnson, C. Shaw, R. F. Murphy, and K. D. Buchanan. 1988. Gastrin releasing peptide (GRP) immunoreactivity in the rat retina: a radioimmunoassay, immunohistochemical and chromatographic study. Brain Res. 447:239-245.

5. Haraguchi, Y., A. Sakamoto, T. Yoshida, and K. Tanaka. 1988. Plasma GRP-like immunoreactivity in healthy and diseased subjects. Gastroenterol. Jpn. 23:247-250.

6. Bork, E., M. Hansen, P. Urdal, E. Paus, J. J. Holst, S. Schifter, M. Fenger, and F. Engbaek. 1988. Early detection of response in small cell bronchogenic carcinoma by changes in serum concentrations of creatine kinase, neuron specific enolase, calcitonin, ACTH, serotonin, and gastrin releasing peptide. Eur. J. Cancer \& Clin. Oncol. 24:10331038.

7. Holtzer, P. 1988. Local effector functions of capsaicin-sensitive sensory nerve endings: involvement of tachykinins, calcitonin-gene related peptide and other neuropeptides. Neuroscience. 24:739-768.

8. Helen, P, P. Panula, H. Y. T. Yang, A. Hervonen, and S. I. Rapaport. 1984. Location of substance P-, bombesin-gastrin-releasing peptide, $\left[\mathrm{met}^{5}\right]$ enkephalin- and $\left[\mathrm{met}^{5}\right]$ enkephalin- $\mathrm{arg}^{6}-$ phe $^{7}$-like immunoreactivities in adult human sympathetic ganglia. Neuroscience. 12:907-916.

9. Kentrote, S., W. L. Dees, and S. M. McCann. 1988. Evidence for a physiological role of hypothalamic gastrin-releasing peptide to suppress growth hormone and prolactin release in the rat. Proc. Natl. Acad. Sci. USA. 85:953-957.

10. Spindel, E. R., M. E. Sunday, H. Hofler, H. J. Wolfe, J. F. Habener, and W. W. Chin. 1987. Transient elevation of mRNAs encoding gastrin releasing peptide (GRP), a putative pulmonary growth factor, in human fetal lung. J. Clin. Invest. 80:1172-1179.

11. Willey, J. C., J. F. Lechner, and C. C. Harris. 1984. Bombesin and the C-terminal tetradecapeptide of gastrin releasing peptide are growth factors for normal human bronchial epithelial cells. Exp. Cell Res. 153:245-248.

12. Cuittitta, F., D. N. Carney, J. Mulshine, T. W. Moody, J. Fedorko, A. Fiscler, and J. D. Minna. 1985. Bombesin-like peptides can function as autocrine growth factors in human small cell lung cancer. Nature (Lond.). 316:823-826.

13. Alexander, R. W., J. R. Upp, Jr., G. J. Poston, V. Gupta, C. M. Townsend, Jr., and J. C. Thompson. 1988. Effects of bombesin on growth of human small cell lung carcinoma in vivo. Cancer Res. 48:1439-1441.

14. Lundgren, J. D., N. L. Ostrowski, J. N. Baraniuk, M. A. Kaliner, and J. H. Shelhamer. 1988. Gastrin releasing peptide causes glycoconjugate release from feline airway organ cultures. Clin. Res. 36:803A.

15. Shinozaki, H., and A. Funokoshi. 1988. Evidence for the direct action of gastrin releasing peptide (GRP) on amylase secretion from rat pancreatic acini: an assessment using a perfusion system. Jpn. J. Physiol. 38:299-307.

16. Damg'e, C., A. Hajri, E. Lhoste, and M. Aprahamian. 1988. Comparative effect of chronic bombesin, gastrin releasing and caerulein on the rat pancreas. Regul. Pept. 20:141-150.

17. Holst, J. J., S. Knuhtsen, C. Orskov, T. Skak-Neilsen, S. S. Poulsen, S. L. Jensen, and O. V. Nielsen. 1987. GRP nerves in pig antrum: role of GRP in vagal control of gastrin secretion. Am. J. Physiol. 253:G643-G649. 
18. Lenz, H. J. 1988. CNS regulation of gastric and autonomic functions in dogs by gastrin releasing peptide. Am. J. Physiol. 255:G298-G303.

19. Walsh, J. H. 1988. Peptides as regulators of gastric acid secretion. Annu. Rev. Physiol. 50:41-63.

20. Baraniuk, J. N., G. D. Raphael, M. Merida, and M. Kaliner. 1988. Histochemical localization of macromolecules secreted by nasal mucosa. Am. Rev. Respir. Dis. 138:413. (Abstr.)

21. Lundgren, J. D., C. J. Wiedermann, C. J. Logun, J. Plutchok, M. Kaliner, and J. H. Shelhamer. 1989. Substance P receptor mediated secretion of respiratory glycoconjugate from feline airways in vitro. Exp. Lung Res. 15:17-29.

22. Shelhamer, J. H., Z. Marom, and M. A. Kaliner. 1980. Immunologic and neuropharmacologic stimulation of mucous glycoprotein release from human airways in vitro. J. Clin. Invest. 66:1400-1408.

23. Login, G. R., S. J. Schnitt, and A. M. Dvorak. 1987. Methods in laboratory investigation: rapid microwave fixation of human tissues for light microscopic immunoperoxidase identification of diagnostically useful antigens. Lab. Invest. 57:585-591.

24. Raphael, G. R., H. M. Druce, J. N. Baraniuk, and M. A. Kaliner. 1988. Pathophysiology of rhinitis 1 : assessment of the sources of protein in methacholine-induced nasal secretions. Am. Rev. Respir. Dis. 138:413-420.

25. Moran, T. H., T. W. Moody, A. M. Hostetler, P. H. Robinson, M. Goldrich, and P. R. McHugh. 1988. Distribution of bombesin binding sites in the rat gastrointestinal tract. Peptides (NY). 9:643-649.

26. Kris, R. M., R. Hazan, J. Villines, T. W. Moody, and J. Schlessinger. 1987. Identification of the bombesin receptor on murine and human cells by cross-linking experiments. J. Biol. Chem. 262:1121520.

27. Rogers, A. W. 1984. Practical Autoradiography. Review 20. Amersham Corp., Arlington Heights, IL.

28. Raphael, G., M. Huptschein-Raphael, and M. A. Kaliner. 1989. Gustatory rhinitis: a syndrome of food induced rhinorrhea. $J$. Allergy Clin. Immunol. 83:110-115.

29. Marom, Z., J. Shelhamer, and M. Kaliner. 1984. Nasal mucus secretion. Ear Nose \& Throat J. 63:36-44.

30. Polak, J. M., and S. R. Bloom. 1985. Occurrence and distribution of regulatory peptides in the respiratory tract. Recent Results Cancer Res. 99:1-16.
31. Uddman, R., and F. Sundler. 1986. Innervation of the upper airways. Clin. Chest Med. 7:201-209.

32. Khalil, Z., P. V. Andrews, and R. D. Helme. 1988. VIP modulates substance P-induced plasma extravasation. Eur. J. Pharmacol. 151:281-287.

33. Brain, S. D., and T. J. Williams. 1988. Substance $P$ regulates the vasodilatory activity of calcitonin gene related peptide. Nature (Lond.). 335:73-75.

34. Panula, P., H. A. Hadjiconstantinou, and T. Yang. 1983. Immunohistochemical localization of bombesin/gastrin releasing peptide and substance $P$ in primary sensory neurons. J. Neurosci. 3:20212029.

35. Lundblad, L. 1984. Protective reflexes and vascular effects in the nasal mucosa elicited by activation of capsaicin-sensitive substance P-immunoreactive trigeminal neurons. Acta Physiol. Scand. Suppl. 529:1-42.

36. Hua, X. Y. 1986. Tachykinins and calcitonin gene related peptide in relation to peripheral functions at capsaicin-sensitive neurons. Acta. Physiol. Scand. 127:1-45.

37. Saria, A., C. R. Martling, Z. Yan, E. Theodorsson-Norheim, R. Gamse, and J. M. Lundberg. 1988. Release of multiple tachykinins from capsaicin-sensitive sensory nerves in the lung by bradykinin, histamine, dimethyl piperazinium, and vagal nerve stimulation. $A m$. Rev. Respir. Dis. 137:1330-1335.

38. Geppetti, P., C. A. Maggi, F. Perretti, S. Frilli, and S. Manzini. 1988. Simultaneous release by bradykinin of substance $P$ and calcitonin gene related peptide immunoreactivities from capsaicin-sensitive guinea pig heart. Br. J. Pharmacol. 94:288-290.

39. Davis, B., A. M. Roberts, H. M. Coleridge, and J. C. G. Coleridge. 1982. Reflex tracheal gland secretion evoked by stimulation of bronchial C-fibers in dogs. J. Appl. Physiol. 53:985-991.

40. Barnes, P. J. 1986. Asthma as an axon reflex. Lancet. i:242245.

41. Aguayo, S. M., M. A. Kane, T. E. King, Jr., M. I. Schwartz, L Grauer, and Y. E. Miller. 1989. Increased levels of bombesin-like peptides in the lower respiratory tract of asymptomatic cigarette smokers. J. Clin. Invest. 84:1105-1113.

42. Tabassian, A. R., E. S. Nylen, R. I. Linnoila, R. H. Snider, M. M. Cassidy, and K. L. Becker. 1989. Stimulation of hamster pulmonary neuroendocrine cells and associated peptides by repeated exposure to cigarette smoke. Am. Rev. Respir. Dis. 140:436-440. 